\title{
Weekly Money Announcements: New Information and Its Effects
}

\author{
Richard G. Sheehan
}

HE consensus among economists is that monetary policy has its primary effects over relatively long time intervals - that is, quarters or years rather than days or weeks. Financial market participants, however, devote considerable attention to the weekly money stock announcement, despite substantial "noise" in the series." Moreover, some economists recently have "discovered" that an announcement of an unexpectedly large money stock increase causes interest rates and U.S. exchange rates to rise and stock prices to fall. ${ }^{2}$

At first glance, the weekly impacts on financial markets may seem to contradict the consensus that money has its primary effects over longer horizons. In this paper, we show why money stock announcements may have an impact on fnancial market variables on a daily or weekly basis even though the principal effects of monetary policy are felt over substantially longer periods. The explanation for this apparent contradiction is the adjustment of financial markets to new information. The focus is on financial markets since their adjustments to new information tend to be more rapid than the adjustments of other markets. The paper examines three hypotheses that relate money stock surprises to financial market prices, the relationships between these hypotheses and the existing empirical evidence that attempts to discriminate between the hypotheses.

Richard G. Sheehan is an economist at the Federal Reserve Bank of St. Louis. Larry J. DiMariano and Michael L. Durbin provided research assistance.

That is, much of the week-to-week movements in the money stock are unrelated to any econoricic phenomenon. See Pierce (1981).

2For a sample of these results, see Cornell (1983b), Hardouvelis (1984), and Urich and Wachtel (1984).

The standard assumption is that financial market prices adjust rapidly to changes in their determinants, within a span of hours or at most days, while prices in other markets tend, for a variety of reasons, to adjust more slowly. See Fama (1982).

\section{MONEY ANDOUNCWMUETS AND

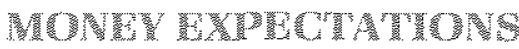

Before examining the effects of money announcements, one must begin with an obvious observation: the money stock announcement itself does not create money. It does, however, create new information about the money stock. At the time of the announcement, the level of the money stock to be announced has already been determined. Thus, any response resulting from the announcement is due to new infor. mation mather than new money. In the following analysis, it will be important to distinguish between these two.

Announcements about the weekly money stock typically are made on Thursday afternoons at 4:30 p.m. EST; at this time the Federal Reserve Board releases figures on the stock of money (M1) for the statement week ending 10 days earlier. If changes in the money stock itself have an immediate impact on financial markets, that impact will begin to be felt almost two weeks before the announcement when the money stock itself changed."

The evidence discussed below suggests that the money stock announcements themselves appear to

\footnotetext{
Information also is released on the monetary base for the week ending one day earlier, the components of the money stock and the monetary base, and the aggregate portfolio of weekly reporting banks.

The hypothesized short-run impact on interest rates of changes in the money stock is termed the "liquidity effect." For example, the Federal Reserve may buy government securities and in so doing provide currency and reserves. To convince economic agents to part with the securities in exchange for money, the Federal Reserve's purchase of securities will bid the price of securities up, thus bidding the yield down. This liquidity effect occurs as soon as the stock of money is increased. See Brown and Santoni (1983) for evidence about the existence, magnitude and duration of the liquidity effect
} 
influence interest rates independent of any effect that the actual money growth may have had. To explain why the money announcements - which cary only new information - may influence interest rates, one must distinguish between expected and unexpected money announcements.

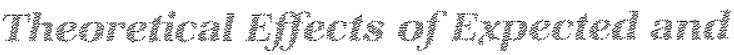

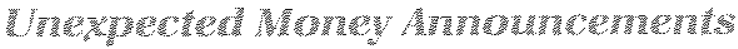

The money stock figures, when announced, are not reported in a vacuum. Financial market participants have substantial information on current and previous interest rates and previous money announcements, allowing them to form expectations about the likely amount of the money stock to be announced. Current asset prices are based in part on expected future economic conditions, including future money stocks. Observers generally believe that if financial markets are effcient, only the unexpected component of the money stock announcement should influence financial variables, The expected component conveys infor mation already digested by the markets and incorporated in the prices and yields of financial assets. Consequently, only surprises matter, not because they provide new money, but because they provide new information that may be useful in predicting policy. makers actions and the behavior of both real and nominal variables. The money stock announcement, to the extent that it is expected, commonly is assumed to have no impact on economic activity.

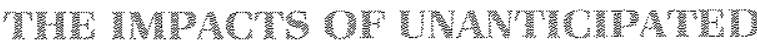

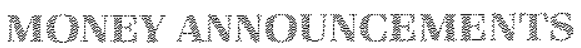

There are a number of hypotheses about why money surprises influence financial market variables. The following sections compare three hypotheses and their underlying assumptions. All three hypotheses are based on the assumption that financial markets efficiently use all available information. Thus, current interest rates, exchange rates and stock prices reflect the implications of the expected future money stocks.

The analysis of the alternative hypotheses is based on the Fisher equation, which divides the current nominal interest rate into the expected real retum over the holding period of the asset and the relevant anticipated rate of inflation. The money announce-

sSee Cornell (1983b) for an explicit statement of this assumption. It should be noted, however, that more general models can be devel. oped in which expected and unexpected announcements are both important. For example, see Belongia and Sheehan (1985b). These more general models have not been widely applied. ment can affect market rates of interest by altering

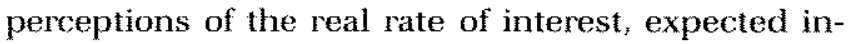
flation or both

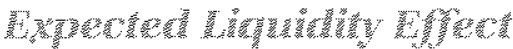

Under this hypothesis, an unexpected change in the money stock that moves it away from its annual target will be followed by changes in the opposite direction to get money growth back on target.' The expected liquidity effect, therefore, is based on the belief that the Federal Reserve has credibility in pursuing its objectives for the money stock. The expected liquidity effect is based on financial market participants believing (1) that Federal Reserve policy is, at least in part, adhering to a long-run monetary aggregate target; (2) that it will take the necessary steps to achieve its target over a relatively short time period; and (3) that such actions will change interest rates.

The impact of an unexpectedly large money stock announcement based on the expected liquidity effect is illustrated in figure 1. The cone formed by the solid lines in figure 1 represents the Federal Reserve's target range for money growth." At any point in time, market participants know past announced money stock levels and have formed expectations about the future path of the money stock, given by the line $\dot{m}$ in figure 1 . The slope of this line represents financial markets' expectations of the money growth rate based on available information, including some estimate of the fed's desired short-run growth rate.

Unexpected money deviations here refer exclusively to those as seen by financial market participants. The money announcement jtself is assumed to reveal no information to the Federal Reserve. See Urich (1982).

While there may be professional debate over the impact of monetary policy on the real interest rate, there is general agreement among economic textbooks that monetary policy does play a significant role. For example, see Dombusch and Fischer (1984).

Money growh in this and the following sections refers exclusively to M1 growth since data on the M2 and M3 monetary aggregates are released only monthly. The Federal Reserve is required by Congress to state target ranges for all three monetary aggregates.

${ }_{10}$ To focus on the expected liquidity effect and the impact of an unexpected money shock, we temporarily abstract from the noise in the series. In lact, the actual money stock numbers on a week-toweek basis as initially reteased form a saw-toothed pattem with an upward trend. In a more realistic setting, expected money may also be expected to fluctuate substantialy as market participants attempt to adjust their forecasts due to a host of changing economic and insitutional factors.

The most common measure of expected money is the median of a survey of market expectations of money growh conducted weekly by Money Market Services, Inc. A time series forecast is infrequently used instead. Regressions of actual money changes on expected money changes indicates that about 30 percent of all money changes are expected. Thus, money changes have a large random component, but are not entirely unpredictable. 
Figure 1

\section{Expected liguidity Effect}

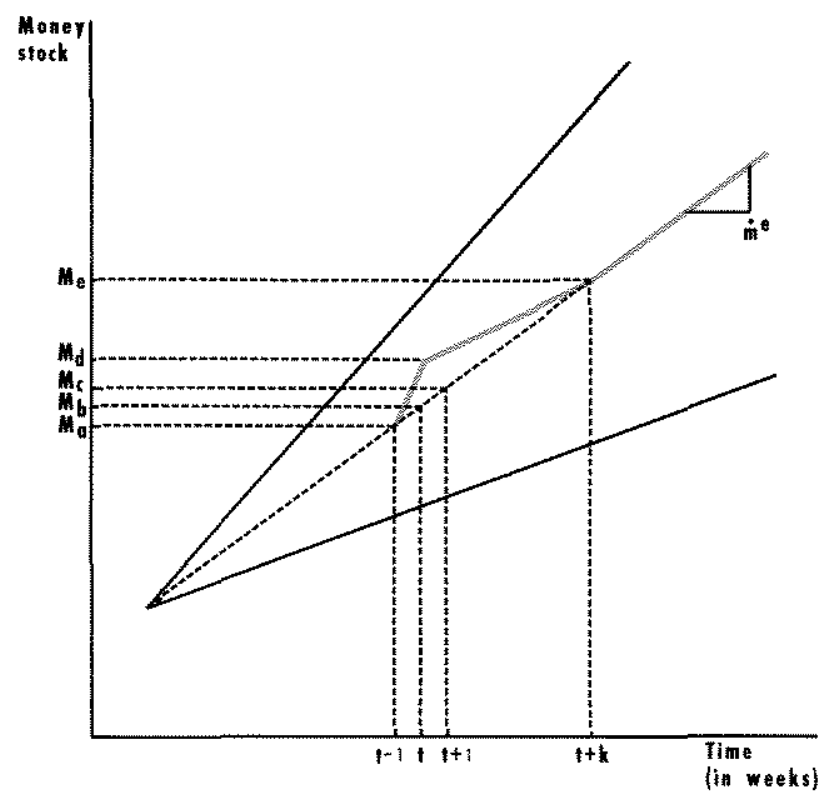

To focus on the expected liquidity effect, assume that the money stock for the week announced previously was $M_{3}$. Just before the money announcement, interest rates, exchange rates and stock prices reflect the assumption that $\mathrm{M}_{\mathrm{b}}$ is the money stock to be announced. Further assume that the announcement of the money stock during week $t$ is then made and reveals that the money stock was, in fact, $\mathrm{M}_{a}$ rather than $\mathrm{M}_{\mathrm{t}+}$

The expected liquidity effect assumes that financial markets believe the Fed will adhere to its previous policy and will take action to return the money stock to its expected path." "This temporary tightening may begin even before the money announcement, since the Fed develops estimates of the money stock before its announcement. During this period, higher nominal interest rates will be expected. If the long-run growth rate in the money stock is assumed to remain unchanged, the rate of expected inflation should also remain unchanged. Thus, short-term real interest rates should rise as short-term nominal wates rise.

\footnotetext{
1) The analysis in figure 1 is presented in terms of money growth vis-avis its expected growth rate. Alternately, it is possible that no reaction (of a smaller reaction) would be expected until the money stock went outside of the Fed's stated arget range. For example, see Roley (1983).
}

Long-term rates will rise to the extent that they are an average of the current short-term rate and expected future rates.

The strength of the expected liquidity effect may vary over time. ${ }^{12}$ A deviation of announced from expected M1 will typically have a larger effect on interest rates when market participants think the Fed is plac ing greater emphasis on controlling M1. Thus, the expected liquidity effect should have been stronger from October 1979 to September 1982 when the Federal Reserve targeted on nomborrowed reserves as an intemediate target.

It is not widely recognized that the expected liquidity effect also makes an assumption about the permanence of the shock underlying the unexpected change in money, assuming the Fed is not the cause of the shock. If the cause is temporary for example, a winter snowstorm delaying check clearance - no Fed intervention is required. When the disturbance is removed, the stock of money will return to its expected growth path even withou Federal Reserve intervention. A movement from $M_{\mathrm{a}}$ to $\mathrm{M}_{\mathrm{d}}$ during week $t$ will still be expected to yield money stock $M_{y}$ in week $t+k$ even without Fed intervention. Thus, a positive shock per ${ }^{m}$ ceived as temporary will not result in expected monetary tightening of higher interest rates. In contrast, if the shock is perceived to be permanent, then discretionary policy action will be required to retum to the expected path as discussed above.

If the change is temporary but the adjustment back to the expected path is slow, policy action may be expected. For example, if delays in processing tax refunds were an important but temporary factor in lowering money growth, the Fed might act to offset factors that would otherwise result in a temporary

\footnotetext{
2For example, see Roley and Walsh (1984) and Gavin and Karamouzis (1984). The most important institutional change was the switch in the Federal Reserve's operating procedures for conducting monetary policy. Before October 6, 1979, the Federal Reserve primarily focused on interest rates in the short run, although there were explicit monetary aggregate targets since 1975; see Wallich and Keir (1979). From October 1979 through September 1982, to improve monetary control, the Federal Reserve adopted a policy of targeting on nonborrowed reserves in the short run. Since then, the Federal Reserve has pursued a more llexible policy, paying somewhat more attention to interest rate fluctuations than it had in the previous period, although not reverting to the pre-October 1979 regime. See Wallich (1984) and Gilbert (1985).

Institutional changes since 1977 also include changes in the money stock announcement dale (switched from Thursday to Friday and back to Thursday), a change from lagged to contemporaneous reserve requirements (in February 1984), and the changes associated with firancial deregulation. Any of these, in theory, could alser the informational content of the money stock announcement.
} 
decline in the money stock. Thus, the expected liquidify effect is also predicated on the assumption that the cause of an unexpected money change is permanent lor of long enough duration to prompt an expectation of Federal Reserve intervention).

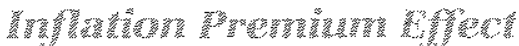

The inflation premium hypothesis, like the expected liquidity hypothesis, focuses on market perceptions of Federal Reserve behavior in response to money surprises. In sharp contrast to the expected liquidity effect, this hypothesis assumes that the Federal Reserve will not react to offset unexpected money fluctuations.

Again assume the Federal Reserve has a target range for money growth given by the cone in figure 2 , and the dashed line represents expected money growth. The last announced value of the money stock was $M_{y}$, and $M_{1}$ is the level expected to be announced in the current week. Also assume the actual announced value is $\mathrm{M}_{\mathrm{d}^{\prime}}$ yielding a positive money surprise of $\mathrm{M}_{\mathrm{a}}-\mathrm{M}_{\mathrm{b}}$.

The inflation premium effect assumes that the surprise will not be offset but that the money surprise will induce (or is the result of changes in the Federal Reserve strategy toward less restrictive monetary policy. Thus, the money stock is not expected to return to its former target path but is expected to move along a new path as indicated by $\dot{m}_{1}^{\prime \prime}$ in figure 2 . The slope of this new path generally will be greater than that of the previous expected path, which indicates higher expected money growth and thus higher expected inflation. ${ }^{13}$ The inflation premium effect predicts that the increase in expected inflation will lead to higher nomi nal interest rates for as long as this inflationary policy is expected to last.

A crucial assumption underlying the inflation premium effect is that an increase in the money stock, at least in part, signals an easier monetary policy stance." An unexpected increase in the money stock

Isff the slope along $\dot{m}_{1}^{e}$ is less than that along $\dot{m}^{\mathrm{e}}$, the two paths will ultimately converge, as they are assumed to do in the analysis of the expected liquidity effect. Alternately, the growth path could have exactly the same slope, $\dot{\mathrm{m}}_{\mathrm{i}}^{\mathrm{e}}=\dot{\mathrm{m}}_{\mathrm{r}}^{\mathrm{e}}$, before and after an unexpected increase in the money stock. In this case, money growth belore and after the one-week shock would be expected to be the same. The long-run money growth rate would increase only by the amount that the one-week increase had an impact on the average. Since money growth influences inflation only with a substantial lag and since a one-shot level change in the money stock is generally small in relation to, say, the year-to-year change in the money supply, a simple step up in the level of the money stock would usualiy have little effect on the actual or the expected inflation rate.

${ }^{14}$ Again, this discussion assumes financial markets believe the Fed is using a single target within the cone.

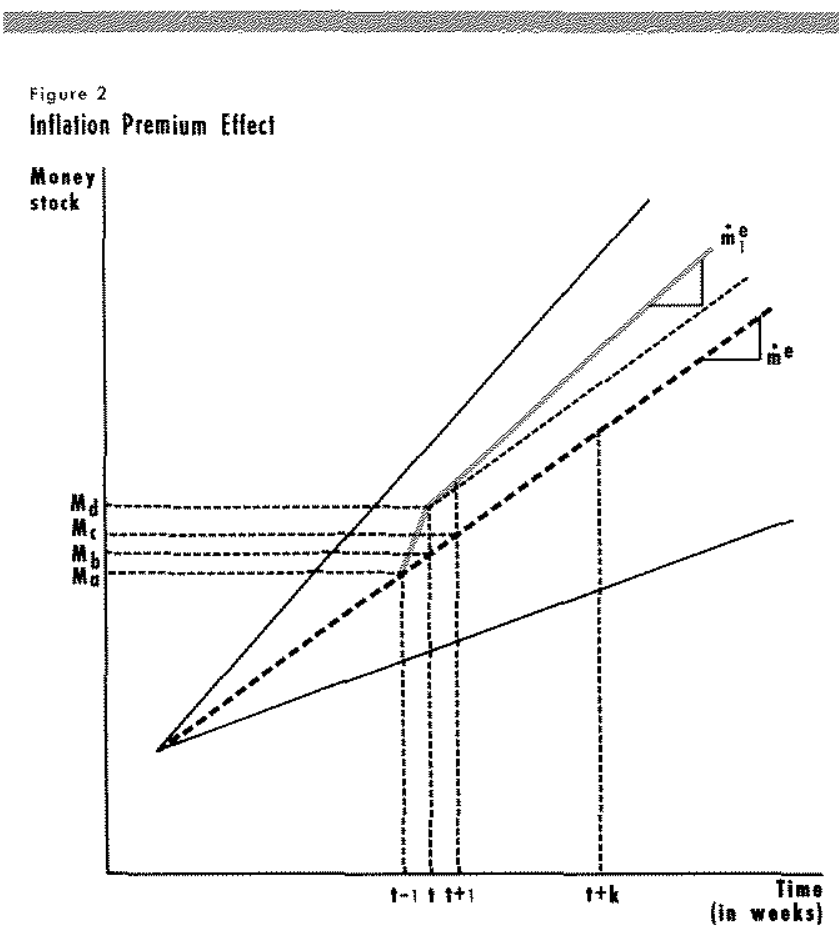

14.

announcement leads financial market participants to revise upward their perceptions of expected future money growth and expected inflation. What does this assumption imply about financial market participants' view of Federal Reserve policy? To the extent that the Fed has stated monetary aggregate targets, market participants must believe that those aggregates may not be the sole target of policy.

The inflation premium effect, like the expected liquidity effect, also assumes that unexpected shocks are perceived as permanent or only slowly selfcorrecting. If the shock were perceived as temporary, Fed intervention would be unnecessary, and money growth would return to its original expected path without Fed intervention. ${ }^{3.5}$

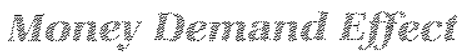

A third hypothesis suggested as an explanation of positive money surprises leading to interest rate increases focuses on money demand effects. ${ }^{\text {ti }}$ Suppose

\footnotetext{
15This statement also abstracts from considerations such as interest rate smoothing. For example, a temporary shock may lead to Fed intervention to smooth the adjustment to equilibrium. In addition, if the shock were temporary but led to a permanent shift in Fed policy, it could also have the effect shown in figure 2.

15 This effect has also been titled the real economic activity effect. See
} Cornell (1983b). 


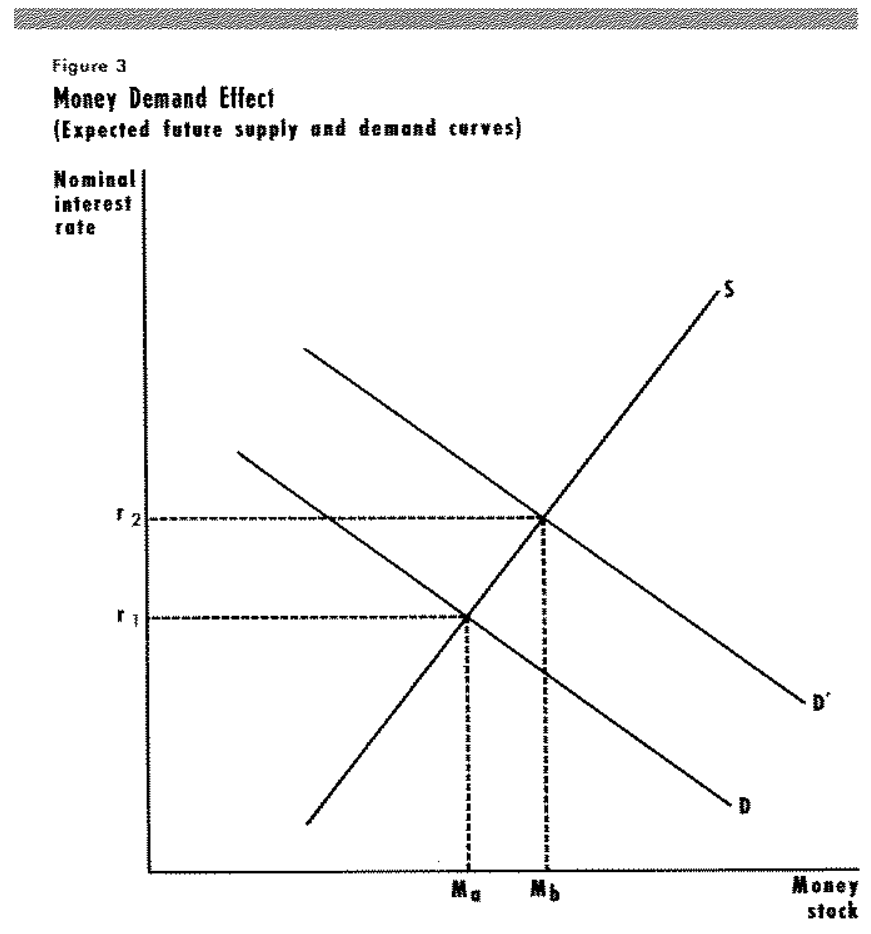

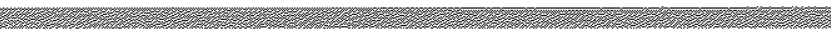

money demand depends in part on expected future output, a situation considered by Fama (1982). Since expectations about future output are unobservable, financial market participants cannot determine aggregate money demand. The money announcement then conveys information not only about money demand but also about expected future output. An increase in money demand due to an increase in expected future output is expected to persist and cause interest rates to be bid up. This effect is illustrated in figure 3 , which focuses directly on market perceptions of money supply and demand. While an increase in money demand may lead market participants to also expect an increase in money supply, it is assumed in this section that only the money demand curve has shifted. The case of money demand and supply both changing is discussed below.

Before the money stock announcement, the expected future money supply and demand curves are given by $S$ and $D$, respectively. After an unexpectedly large money announcement, the future money demand curve is perceived to have shifted (permanently) from $D^{\prime}$ to $D^{\prime}$. Interest rates in the future are expected to rise to equilibrate the money market, and the expectations of higher future rates lead current rates to rise in anticipation. Note that it is the new information about the location of the present and expected future demand curves that influences interest rates. Any ac- tual shift in the demand curve, subject to the limitations noted above, would already have had its impact felt before the announcement ${ }^{z}$

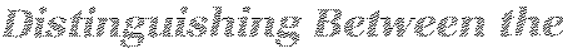

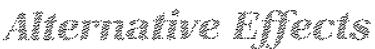

The three effects described above all predict that an unexpected money stock increase will lead to higher nominal short-term interest rates. In an effort to differentiate the impacts of the expected liquidity effect, the inflation premium effect and money demand effect, some studies have examined the implications of the alternative effects on stock prices and exchange rates. ${ }^{\text {ts }}$

Based on the expected liquidity effect, some have argued that, because the money surprise leads to higher expected interest rates, it depresses the present discounted value of future dividends, thus lowering stock prices. In addition, the expected iquidity effect predicts that, after taking into account exchange rate risk, higher expected real returns in the United States relative to, say, Germany should induce a capital inflow that will be accompanied by a rising value of the dollar vis-a-vis other currencies.

The inflation premium effect predicts that an unexpected money stock increase will lower exchange rates, as U.S. inflation increases relative to inflation in other countries. The inflation premium effect makes no prediction about the effect of an unexpected money stock increase on stock prices. ${ }^{19}$

${ }^{17} \mathrm{~A}$ shift in money demand that is not due to a shift in expected futtre output is not necessarily asscciated with any change in stock prices.

One particular money demand effect that is sometimes considered separately is the reserve settlement effect. This effect existed only under lagged reserve requirements when the timing of the money announcement was such that it revealed iniomation about current reserve demand. Consider a money stock announcement, say, on August 26, 1982. Data on the money stock was released then for the week ending August 18, 1982. But deposits for the week ending August 26, 1982, determined required reserves for the week ending September 2, 1982. When the money stock numbers were peleased, they may have contained incremental information on the demand for reserves.

An individual bank may know its own reserve requirements prior to the money announcement, but it has onty limited information on aggregate reserves and thus on the federal funds rate expected to preval for the remainder of the reserve settlement period. An unexpected money increase generaly implies that deposits, as well as the demand for requited and total reserves, are all greater than expected. The reserve settlement effect demonstrates how institutional characteristics can influence the relationship, say, between money announcements and interest rates.

18For example, see Conell (1983b).

"9See Comell (1983b) for a more detailed explanation. 
In contrast, the money demand effect implies that an unexpectedly large money announcement will increase stock prices due to the underlying increase in expected future output. The international value of the U.S. dollar may increase due to the direct impact of an increased money demand as well as the indirect effect of greater money demand leading to higher real interest rates and resulting capital inflows.

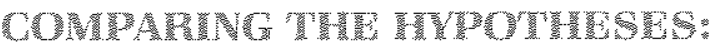

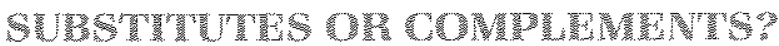

Previous studies have advanced the three hypotheses presented above as competing theories to explain why unanticipated money announcements alter financial market variables ${ }^{2}$ in fact, the three effects do not necessarily compete and may be either substitutes or complements. Consider a simple example in which they are complements. As in figures 1 and 2 , the expected money stock prior to the announcement at time $t$ was $M_{b}$, while the announced value was $M_{a}$. The expected liquidity effect again predicts a slowing of money growth from time $t$ to $t+k$. Assume that this tightening is expected to be only partially successful. In terms of figure 2 , the money growth rate will be between $\dot{m}^{*}$ and $\dot{m}_{1}^{*}$. In this scenario, nominal interest rates will be expected to rise due to both the expected restrictive policy and higher expected inflation. Simply stated, monetary policy is expected to be tighter after the unexpected increase, but not tight enough to restore the former growth rate.

Figures 1 to 3 each focus on one monetary disturbance. There is, however, substantial noise in the weekly M1 series. Thus, temporary shifts cannot readily be distinguished from permanent shifts. Furthermore, in light of this uncertainty which all financial market participants face, the Federal Reserve may be expected to hedge its response to fluctuations. ${ }^{22}$ Thus, it is plausible that market participants may expect monetary policy to be tighter after an unexpected increase, but not tight enough to restore the former growth rate.

Both the expected liquidity and the inflation pre-

It shouid be noted that the relationship between real interest rates and capital inflows has only recently been emphasized. See Batten and Ot ( 1983). Previously the emphasis would have been placed on relationships like an expected expansion leading to a rise in imports and a drop in the U.S. exchange rate.

"In fact, Cornell (1983b) introduces an additional theory, the risk prenium hypothesis, based on increased monetary variability requining larger risk premiums. Since neither he nor Belongia and Kolb (1984) found any evidence of its existence, it is omitted here.

aSee Brainard (1967) for a formal model making this point. mium effects are based on the assumption of a perma nent money market shock that may prompt Federal Reserve response. While such a shock need not originate in money demand, clearly it could. If it does, then the expected liquidity and inflation premium effects cannot be distinguished from the money demand effect.

Further complicating the analysis of the money demand effect is that it presumes a shift in money demand, but market participants are unlikely to believe money demand can shift without some Fed response based on its presumed targets. Thus, the money demand effect may imply, say, an expected liquidity effect in response. For example, assume money demand increases and the Federal Reserve is believed to be focusing exclusively on a monetary aggregate target. The increase in money demand, ceteris paribus, will lead to increases in both the money stock and interest rates as figure 3 demonstrates. Furthermore, the announcement of a money stock increase could lead financial market participants to $\mathrm{EX}^{-}$ pect the fed to reduce the money supply in order to maintain its monetary aggregate target. This tighten ing, however, is the expected liquidity effect.

Altemately, if financial market participants believe the Federal heserve is trying to peg nominal interest rates, the expected Fed response to a money demand increase would be very different. An increase in money demand would prompt the Fed to increase the money supply to prevent interest rates from increasing. In this scenario, the unexpected money announcements should have no effect on interest rates. Between the extremes of focusing exclusively on interest rates and focusing exclusively on a monetary aggregate, both the expected liquidity and inflation premium effects may be present.

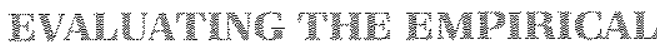

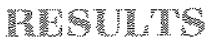

The findings of previous empirical analyses of the impact of anticipated and unanticipated money announcements are summarized in table 1 . The results presented indicate considerable disagreement among previous studies.

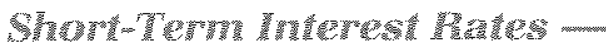

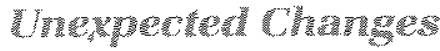

Most studies conclude that short-term interest rates are significantly and positively influenced by unanticipated money announcements. While this is true in both the pre- and post-October 1979 periods, the ef- 


\section{Table 1}

Summary of Empirical Results

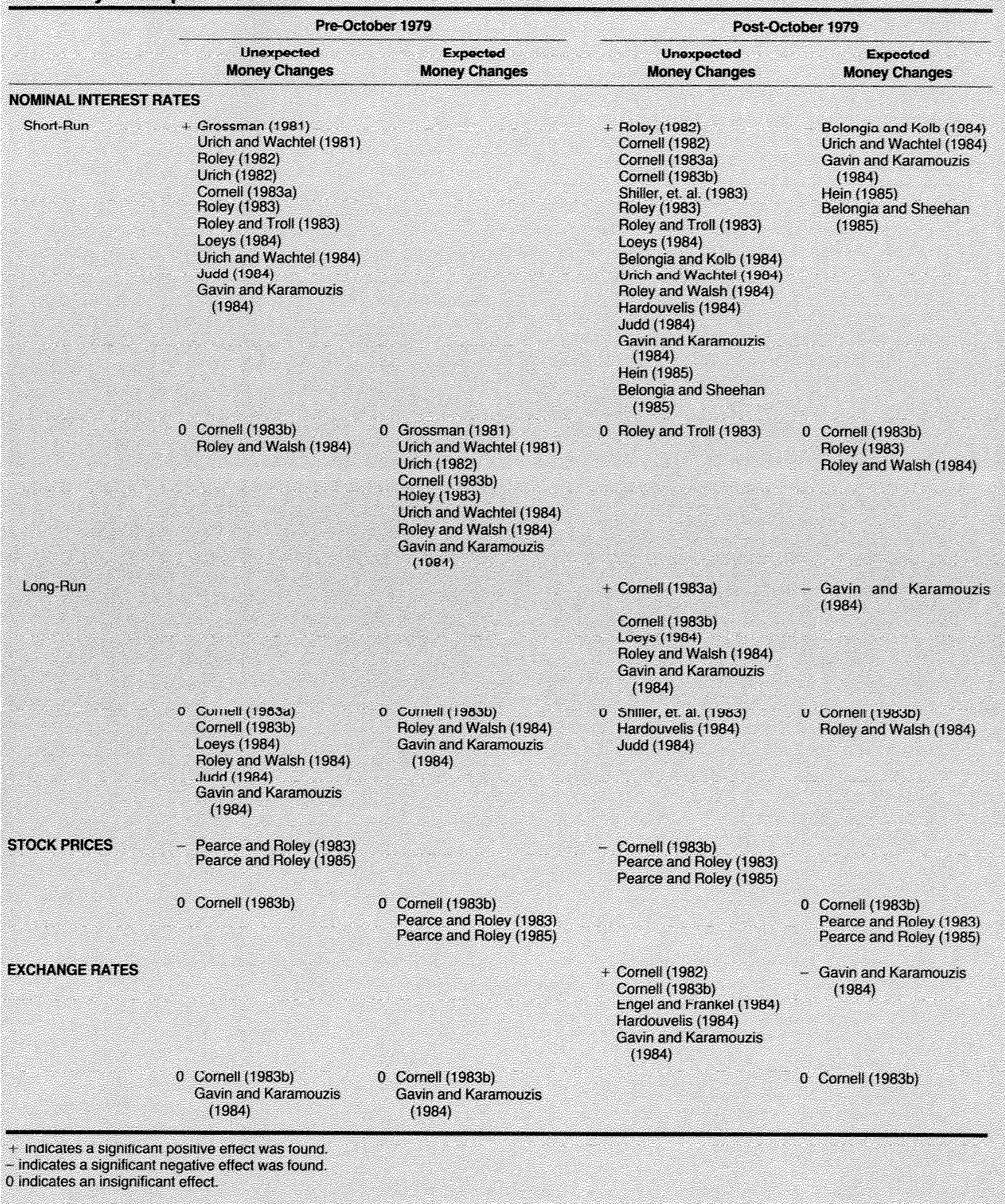


fects are substantially larger in the latter period. ${ }^{23}$ For example, Judd (1984) finds that a 1 percent positive money surprise would increase the three-month Treasury bill rate by only 6 basis points before October 1979 , but by 36 basis points after September 1979.* That this is true is consistent with financial markets believing that after September 1979 the Fed placed substantially more weight on short-term money stock movements in their efforts to achieve monetary aggregate targets. Apparently, the market believed the Fed's statements that its procedures were being changed. The very small estimated coefficients before October 1979 indicate that financial markets believed the fed was less interested in short-term movements in the money stock before then.

That an unexpectedly large money announcement increases short-term nominal interest rates cannot be used as evidence to distinguish between the expected liquidity, inflation premium and money demand effects, however. All three predict a positive relationship between the two.s Thus, previous research also has

\begin{abstract}
${ }^{23}$ There is also substantialy greater interest rate volatility in the latter period. In addition, studies that have attempted to assess the impact of money suppises have been faced with the task of sorting out the influences of other factors such as a change in the day of the money announcement, a discount rate surcharge, credit controls, etc. See also the institutional changes mentioned in footnote 12 . Most studies have simply chosen a pertod (or periods) for analysis and assumed that non-money-announcement effects were unchanging over that period. Whether this approach is valid is debatable. It should be noted, however, that most estimated equations can explain only 30 percent or less of the fluctuation in interest rates around the time of the money announcement.

${ }^{24}$ In general, no attempt is made here to present the magnitude of estimated coeficients since the studies differ with respect to time periods, definitions of the dependent variable (e.g., federal funds rate vs. three-month Treasury bill as the short-term interest rate) and equation specification. In addition, all the studies excepl Juod (1984). Loeys (1984) and Gavin and Karamouzis (1984) make no systematic study of differential effects occurring after October 1982 when the Feteral Reserve deemphasized the M1 monetary aggre gate.

2Cornel (1983b) states:

The dramatic shif in the market response to money supply announcomonts after October 6 is difficult to reconcile with the expected friflation hypothesis. In the money supply afnomcements are providing information about buture money gtowth there is no obvious reason why the Fed's stated intention to contro monetary aggregates should induce a positive correlation beween announced innovations in money and changes if interest rates. In tact, it is more feasonable to conciude that the corretation would dectine because week-to-week variation in the aggregates wouk no longer provide information about long-run policy.
\end{abstract}

Comel's argument is that the expected liquidity effect predicts a greater response to money surprises pre- vs, postoctober 1979 , While the inflation premium effect predicts no change in response. This lack of change with the inflation premium hypothesis, however, is based on the assumption that the change in operating procedures did not ahe market participants' view of the money supply process. The inflation premium effect could also be associated with a greater response to a money surprise after October 1979 if, for example, an unexpected increase in the money stock after that date is viewed as having a greater probability of signaling monetary ease than under the previous operating procedures. focused on financial market variables for which the responses to money surprises might differ. These variables include long-tem interest rates, stock prices and exchange rates.

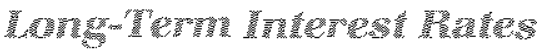

Studies that have considered the impact of money announcements on long-term interest rates have been unanimous in concluding that neither announcement surprises nor anticipations influenced long-term rates prior to October 1979. This is again consistent with financial markets believing that the Federal Reserve was pegging interest rates before October 1979. After September 1979, with limited analysis there is some evidence that expected announcements have no impact on long-term rates. Expected increases in the money stock may lead to higher inflation and higher long-term interest rates, but do not necessarily lead to higher inflation and interest rates immediately after the money announcement.

The results concerning announcement surprises are mixed. Studies that have used long-term forward rates such as Shiller, et. al. (1983), Hardouvelis (1984) and Judd (1984) generally have found no significant response. ${ }^{26}$ These findings are not consistent with the inflation premium effect. A money surprise is apparently expected to be quickly offset by the Fed and thus has no effect on long-run inflation expectations. Alternately, financial market participants could simply believe that weekly money announcements, from a longrun perspective, convey little or no information useful in forecasting long-term interest fates.

Studies such as Comell 1983a) that have used changes in actual long-term rates, which include the effects of short-term rates, have found significant effects. Whether these effects are the result of market participants' short-run expectations about current or prospective short-term interest rates or whether they truly convey information about inflation expectations has not been determined.

\section{Sycher}

Relatively few studies have considered the implications of money announcements on stock prices. Stock prices apparently decreased in response to positive money sumprises in the post-September 1979 period In the pre-October 1979 period, there is no consensus

\footnotetext{
Gavin and Karamouzis (1984) find the four-year forward rate three years ahead is significantly intluenced by money surprises, while

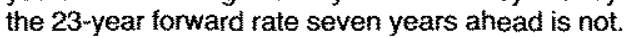


on whether money surprises influenced stock prices (table 1). Expected changes had no effect on stock prices in either period.

These results are inconsistent with the money demand effect. If the money announcement reveals an increase in money demand due to an increase in expected output, stock prices should increase. ${ }^{27}$

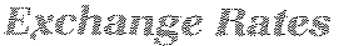

The exchange rate results presented in table 1 indicate that neither anticipated announcements nor surprises significantly influenced exchange rates before October 1979. After September 1979, money sumprises have resulted in significant appreciation of the dollar relative to some currencies, in particular the German mark and the Swiss franc. Other exchange rates, such as those relative to the British pound and the Cana" dian dollar, have not appreciated significantly. To date, there apparently have been no joint tests of the significance of money surprises on all exchange rates.

The evidence that exchange rates generally did not depreciate is also inconsistent with the inflation premium effect. The inflation premium effect predicts that an unexpectedly large money announcement, associated with higher expected inflation, should lead instead to lower exchange rates. ${ }^{2 x}$

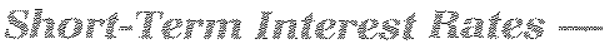

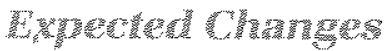

Most studies also indicate that expected money announcements had no impact on short-term interest rates before October 1979. After then, table 1 indicates a consensus that expected money announcements had significant negative effects on short-term interest rates. This result is inconsistent with any of the competing theories and the efficient markets hypothesis. ${ }^{29}$ Thus, either the efficient markets hypothesis is incorrect, the theories as they are currently formulated or tested are insufficiently detailed, or other factors are changing that are correlated with expected money.

${ }^{27}$ This conclusion implies only that the money demand effect by itself cannot explain all of the impacts of the money announcements.

23 The exchange rate results imply only that the inflation premium effect by itself is not capable of explaining all the impacts of money announcements.

${ }^{29}$ After October 1979, an expected increase in the money supply would cause movement down the money demand curve with a resulting decrease in interest rates. Market efficiency implies that this decrease in interest rates would occur immediately upon the change in expectations. Thus, if the money supply is expected to increase prior to the money announcement, interest rates would already have adjusted to this expectation prior to that announcement.
It is difficult to argue that the efficient markets hypothesis is incorrect. If it were, it would imply that profitable trading opportunities exist based only on knowledge of expected money. ${ }^{3 *}$ Given that the money announcement is widely forecasted and both the forecasted and announced values are widely disseminated, it seems unreasonable to expect profitable trading opportunities to remain for long. It seems more plausible to attribute the significance of expected money either to correlation between expected money and omitted variables or to limitations in the underly ing theory.;1

\section{CONGWISTIS}

While a number of theories have been advanced to explain why money stock announcements, particularly the component that is unexpected, influence fnancial market variables, this paper shows that these theories are not generally competing. For example, the expected liquidity and inflation premium effects may be complementary depending on financial market participants' perceptions of Federal Reserve goals. Some empirical results are inconsistent with either the inflation premium effect or the money demand effect alone. The expected liquidity effect, by itself, can explain the responses of interest rates, exchange rates and stock prices to unexpected money announcements. There is no reason, however, to believe that this effect, or either of the two others, operates in isolation.

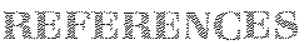

Batten, Dallas S., and Mack Ott. "Five Common Myths About Floating Exchange Rates," this Review (November 1983), pp. 5-15.

Belongia, Michael T., and Fredric Kolb. "Risk Aversion and Weekly Money: Does the Market Expect the Fed to Offset Large Increases in M1?" Economics Letters, vol. 16 (1984), pp. 327-30.

Belongia, Michael T., and Richard G. Sheehan. "The Efficient Mar" kets Hypothesis and Weekly Money: Some Contrary Evidence," Federal Reserve Bank of St. Louis, Working Paper 85-004 (1985a).

"On the Importance of Being Expected: Insights to the Weekły Money Puzzle," Federal Reserve Bank of St, Louis, Working Paper 85-007 (1985b)

Brainard, William C. "Uncertainty and the Effectiveness of Policy," American Economic Review (May 1967), pp , 411-25.

\footnotetext{
3o be precise, the efficient markets hypothesis would allow trading rules to exist with a positive gross return that was less than the transaction costs of making the trades.

${ }^{3}$ See Roley (1983) and Hein (1985) for examples of the former. A full discussion of the potential impacts of expected money is beyond the scope of this paper. For more detalls, see Belongia and Sheehan (1985b).
} 
Brown, W. W., and G. J. Santoni. "Monetary Growth and the Timing of Interest Rate Movements," this Review (August/September 1983), pp. 16-25.

Cornell, Bradford. "Money Supply Announcements, Interest Rates, and Foreign Exchange," Journal of International Money and Finance (August 1982), pp. 201-08.

. "Money Supply Announcements and Interest Rates: Another View," Journal of Business (January 1983a), pp. 1-23.

"The Money Supply Announcements Puzzle: Review and Interpretation," American Economic Review (September 1983b), pp. 644-57.

Dornbusch, Rudiger, and Stanley Fischer. Macroeconomics (McGraw-Hill, 1984).

Engel, Charles, and Jeffrey Frankel. "Why Interest Rates React to Money Announcements: An Explanation from the Foreign Exchange Market," Joumal of Monetary Economics (January 1984), pp. 31-39.

Fama, Eugene F. "Inflation, Output, and Money," Journal of Business (April 1982), pp. 201-32.

Gavin, William T., and Nicholas V. Karamouzis. "Monetary Policy and Real Interest Rates: New Evidence from the Money Stock Announcements," Federal Reserve Bank of Cleveland, Working Paper 8406 (December 1984).

Gilbert, R. Alton. "Operating Procedures for Conducting Monetary Policy," this Review (February 1985), pp. 13-21.

Grossman, Jacob. "The 'Rationality' of Money Supply Expectations and the Short-Run Response of Interest Rates to Monetary Surprises," Joumal of Money, Credit, and Banking (November 1981), pp. $409-24$.

Hater, R. W. "The FOMC in 1983-84: Setting Policy in an Uncertain World," this Review (April 1985), pp. 15-37.

Hardouvelis, Gikas A. "Market Perceptions of Federal Reserve Policy and the Weekly Monetary Announcements," Joumal of Monetary Economics (September 1984), pp. 225-40.

Hein, Scott E. "The Response of Short-Term Interest Rates to Weekly Money Announcements: A Comment," doumal of Money Credit, and Banking (May 1985), pp. 264-71.

Judd, John P. "Money Supply Announcements, Forward Interest Rates and Budget Deficits," Federal Reserve Bank of San Francisco Economic Review (Fall 1984), pp. 36-46.

Loeys, Jan G. "Market Perceptions of Monetary Policy and the Weekly M A Announcements," Federal Reserve Bank of Philadelphia Wofking Paper No. 84-2.

Nichols, Donald A., David H. Small, and Charles E. Webster, Jr.
"Why Interest Rates Rise When an Unexpectedly Large Money Stock is Announced," American Economic Review (June 1983), pp. $383-88$.

Pearce, Douglas $K$, and $V$. Vance Roley. "The Reaction of Stock Prices to Unanticipated Changes in Money: A Note," Joumal of Finance (September 1983), pp. 1323-33 ness (January 1985), pp. 49-67

Pierce, David. "Trend and Noise in the Monetary Aggregates," in New Monetary Control Procedures, Vol. II. Federal Reserve Staff Study, Board of Governors of the Federal Reserve System, Washington, D.C., 1981.

Roley, V. Vance. "Weekly Money Supply Announcements and the Volatility of Short-Term Interest Rates, "Federal Reserve Bank of Kansas City Economic Review (April 1982), pp. 3-15.

"The Response of Shont-Term Interest Rates to Weekly Money Announcements: A Note," Joumal of Money, Credit, and Banking (August 1983), pp. 344-54.

Roley, V. Vance, and Rick Troll. "The Impact of New Economic Information on the Volatility of Short-Term Interest Rates," Federal Reserve Bank of Kansas City Economic Review (February 1983), pp. 3-15.

Roley, V. Vance, and Carl E. Walsh. "Unanticipated Money and Interest Rates," American Economic Review (May 1984), pp. 4954.

Shiller, Robert J., John Y, Campbell, and Kermit L. Schoenholtz. "Forward Rates and Future Policy: Interpreting the Term Structure of Interest Rates," Brookings Papers on Economic Activity (1:1983), pp. 173-217.

Urich, Thomas J. "The Information Content of Weekiy Money Supply Announcements," Journal of Monetary Economics (July 1982) pp. $73-88$.

Urich, Thomas J., and Patl Wachtel. "Market Response to the Weekly Money Supply Announcements in the 1970s," Journal o Finance (December 1981), pp. 1063-72.

"The Effects of Inflation and Money Supply Announce ments on Interest Rates," Journal of Finance (September 1984) pp. $1177-88$.

Walsich, Henty C. "Recent Techniques of Monetary Policy," Fed. eral Reserve Bank of Kansas City Economic Review (May 1984) pp. 21-30.

Wallich, Henry C., and Peter M. Keir. "The Role of Operatin Guides in U.S. Monetary Policy: A Historical Review," Federä Reserve Bulletin (September 1979), pp. 679-90. 